\title{
Incident Precipitation Partitioning: The Canopy Interactions Enrich Water Solution With Nutrients in Throughfall and Stemflow
}

\author{
Dione Richer Momolli ${ }^{1}$, Mauro Valdir Schumacher ${ }^{1}$, Marcio Viera ${ }^{1}$, Aline Aparecida Ludvichak ${ }^{1}$, \\ Claudiney do Couto Guimarães ${ }^{1} \&$ Huan Pablo de Souza ${ }^{1}$ \\ ${ }^{1}$ Department of Forest Science, Santa Maria Federal University, Santa Maria, Brazil \\ Correspondence: Dione Richer Momolli, Department of Forest Science, Santa Maria Federal University, Santa \\ Maria, Brazil. Tel: 55-559-9727-1859. E-mail: dionemomolli@gmail.com
}

Received: February 10, 2019

Accepted: March 19, 2019 Online Published: May 15, 2019

doi:10.5539/jas.v11n6p351

URL: https://doi.org/10.5539/jas.v11n6p351

\begin{abstract}
Atmospheric deposition is responsible for the ions input, which may be due to dust and aerosols and rainfall. During rainfall a portion is intercepted by the tree canopy and returned to the atmosphere by evapotranspiration, another part crosses the forest canopy called throughfall and stemflow. The objective of the present work was to quantify the nutrient input of the incident rainfall, throughfall, stemflow and canopy enrichment in an Eucalyptus dunnii plantation, established in soil with low natural fertility. Four plots of $20 \mathrm{~m} \times 21 \mathrm{~m}$ were demarcated. The rainfall consists 3 rain collectors in an open área. The throughfall consisted 3 collectors per plot in the line, interlining and diagonal positions of the trees. The stemflow consisted in the installation of three systems per plot formed by a hose in the trunk of the tree that leads the solution to a reservoir. Through rainfall, $29.5 \mathrm{~kg} \mathrm{ha}^{-1}$ of nutrients were supplied. When we consider the sum of the throughfall and stemflow, the amount of nutrients was $77.6 \mathrm{~kg} \mathrm{ha}^{-1}$. After interaction with the tree canopy $48.2 \mathrm{~kg} \mathrm{ha}^{-1}$ of nutrients were incorporated. Potassium showed the highest enrichment: $607 \%$. The average nutrient enrichment was $163 \%$. The input of $\mathrm{N}$ and $\mathrm{K}$ via incident rainfall was 1.8 and $3.1 \mathrm{~kg} \mathrm{ha}^{-1}$. Considering the fertilization described in the methodology, this contributed amount represents 6.1 and $2.6 \%$ of the total. If we consider the rotation of 7 years for Eucalyptus dunnii, the contribution at the end of rotation represents 42.4 and $18 \%$ of $\mathrm{N}$ and $\mathrm{K}_{2} \mathrm{O}$. The interaction with the canopy of Eucalyptus dunnii enriches the rainwater with nutrients making the solution with a more basic character.
\end{abstract}

Keywords: forest nutrition, nutrient cycling, sustainability

\section{Introduction}

The growth of the world population has generated the search for the increase of raw material, among them the wood and its multiple products. According to FAO 2015, the expansion of the area occupied by forests grew 5 million hectares between 2000 and 2010. In Brazil, between 1990 and 2015 the area occupied grew at an average geometric rate of $1.8 \%$, even thus slightly below the world average of $2.1 \%$ (FAO, 2015).

This expansion has occurred in areas often without a silvicultural tradition such as the present study in which it is located in the Pampa Biome. In South America this biome occupies a total area of $751,000 \mathrm{~km}^{2}$ (Dixon et al., 2014). About $23.5 \%$ of this area is located in Brazil, more specifically in the southern half of the state of Rio Grande do Sul (Brasil, 2016). This region is characterized by predominantly sandy textured soils, low organic matter content and low natural fertility (Suertegaray \& Silva, 2009).

To maintain forest productivity in these circumstances, it is essential that atmospheric inputs are computed and considered as a source of nutrients. According to Viera and Schumacher 2010, the movement of the nutrients is dynamic, being continuously transferred between the biotic and abiotic means. This transfer can occur through the geochemical cycle, which is characterized by the inputs that come from dry and wet precipitation (Viera \& Schumacher, 2010), which crosses the forest canopy, carries aerosols deposited in the plant tissue and leaches the components of the biomass to the forest floor (Eaton et al., 1973; Schrumpf et al., 2006), representing an important internal flow of nutrients in the forests (Parker, 1983; Bhat et al., 2011; Levia et al., 2011).

The chemical composition of the water from the stemflow and throughfall is a result of the interaction of meteorological factors, distance from the sea, dry depositions and leaching of the canopies (Andre et al., 2008; 
Navar et al., 2009), important for the nutrient supply to the roots of the plants and the maintenance of soil water balance (Wang et al., 2011, 2013; Zhang et al., 2013; Jung et al., 2011). According to Neary and Gizyn (1994), the throughfall and stemflow are important sources for the enrichment of cations. Moreover, when treating soils with low cation and sandy exchange capacity, the leaching process has the role of acid neutralization.

Many studies have shown that nutrient levels increase in the following order: incident precipitation $<$ throughfall $<$ stemflow (Balieiro et al., 2007; Perez-Marin \& Menezes, 2008). In general, the greater contact of rainfall with vegetation biomass increases the nutrient content, as is the case of stemflow Pereira et al. (2009); Nunes et al. (2003).

The objective of the present work was to quantify the nutrient input of the incident rainfall, throughfall, stemflow and canopy enrichment in an Eucalyptus dunnii plantation, established in soil with low natural fertility.

\section{Materials and Methods}

\subsection{Characterization of the Experimental Area}

The study was conducted in Alegrete, state of Rio Grande do Sul, southern Brazil, under the central geographic coordinates of $29^{\circ} 47^{\prime} 10^{\prime \prime} \mathrm{S}$ and $55^{\circ} 17^{\prime} 30^{\prime \prime} \mathrm{W}$. The experiment is located in a watershed with total area of $340.7 \mathrm{ha}$. About $31 \%$ of the area is for conservation, the remaining $69 \%$ is occupied by stands of Eucalyptus sp., being $23.4 \%$ of the total area covered by the species Eucalyptus dunnii. The stand of seminal origin was implanted with spacing $2.5 \mathrm{~m} \times 3.0 \mathrm{~m}$, with an initial density of 1427 trees per hectare. At the time of the study, the trees were between 84 and 96 months old ( 7 to 8 years respectively).

The planting was carried out in November 2008. Subsoiling and fertilization of $300 \mathrm{~kg} \mathrm{ha}^{-1}$ of natural phosphate was carried out in the planting line. After 15 days of planting, $140 \mathrm{~kg} \mathrm{ha}^{-1}$ of $\mathrm{N}-\mathrm{P}_{2} \mathrm{O}_{5}-\mathrm{K}_{2} \mathrm{O}$, formulation 06-30-06, $+0.6 \%$ of boron were incorporated into the soil. The second fertilizer addition was at 90 days after planting, where $140 \mathrm{~kg} \mathrm{ha}^{-1}$ of $\mathrm{N}_{-} \mathrm{P}_{2} \mathrm{O}_{5}-\mathrm{K}_{2} \mathrm{O}$, formulation $22-05-20,+0.2 \%$ of boron $+0.4 \%$ of zinc haul). The third fertilization was at 270 days, using $140 \mathrm{~kg} \mathrm{ha}^{-1}$ of $\mathrm{N}^{-} \mathrm{P}_{2} \mathrm{O}_{5}-\mathrm{K}_{2} \mathrm{O}$, formulation $22-00-18,+1.0 \%$ of sulfur $+0.3 \%$ of boron, applied to haul in the line.

\subsection{The Weather}

The climate of the region is of the wet tempered sub-type Cfa. The variety "Cfa" is characterized by rainfall during all months of the year and has the temperature of the hottest month exceeding $22{ }^{\circ} \mathrm{C}$, and that of the coldest month exceeding $3{ }^{\circ} \mathrm{C}$. The summers can present a period of drought, with average annual temperature of $18.6^{\circ} \mathrm{C}$ and average annual rainfall of $1747 \mathrm{~mm}$ (Alvares et al., 2014). Figure 1 shows the climatic diagram based on the Alegrete-RS meteorological station. The species Eucalyptus dunnii, is still classified with a medium climatic aptitude for the region of Alegrete (Flores et al., 2016).

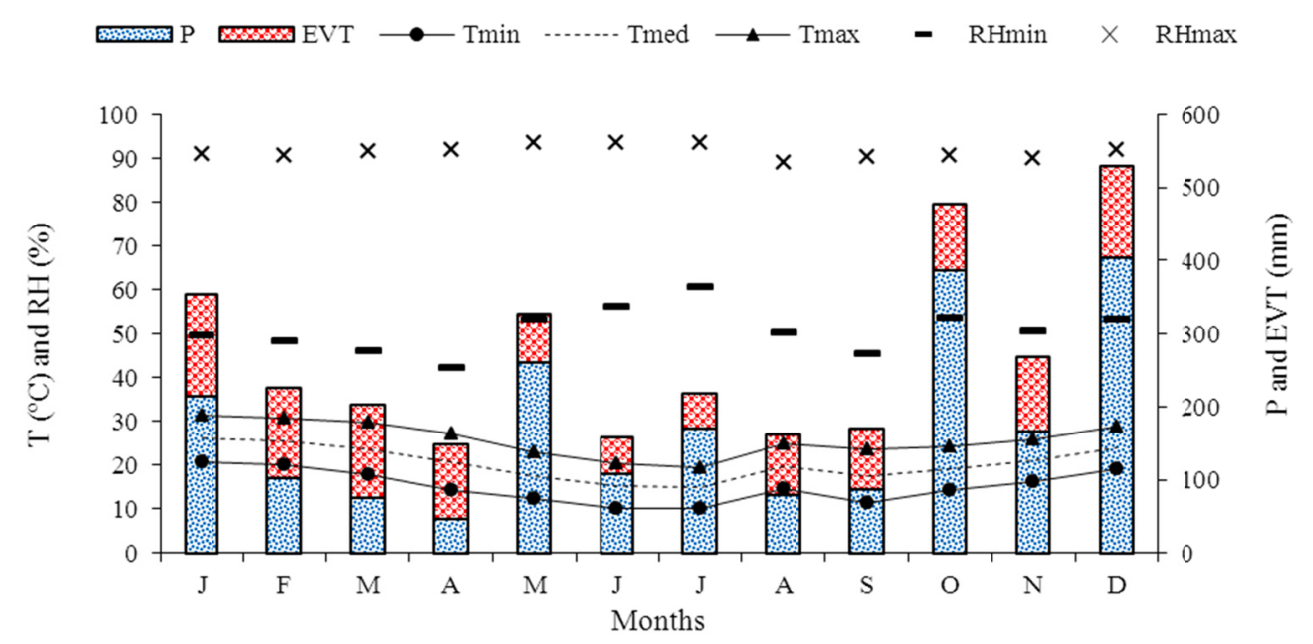

Figure 1. Climatic diagram for the year 2015 in Alegrete-RS

Note. $\mathrm{EVT}=$ evapotranspiration.

Source: AGRITEMPO (2019). 


\subsection{Data Collection}

The monitoring of rainfall $(\mathrm{P})$ occurred with the installation of 3 collectors with a diameter of $20 \mathrm{~cm}$ at $1.5 \mathrm{~m}$ from the ground level. They were allocated in a field area, distant about $50 \mathrm{~m}$ from the plots of the eucalyptus stand. Neoprene straps with galvanized steel wires were placed in order to avoid that they be used as perches for birds.

For the throughfall (Tf), 4 plots were demarcated inside the stand with dimensions of $20 \mathrm{~m} \times 21 \mathrm{~m}$. Then, 3 collectors with a diameter of $20 \mathrm{~cm}$ and height of uptake of $1 \mathrm{~m}$ of the soil level were distributed in the positions line, line and diagonal of the trees in each of the plots.

The determination of the amount of rainfall of the incident precipitation $(\mathrm{P})$ and throughfall $(\mathrm{Tf})$ in $(\mathrm{mm})$ was obtained by the following equation:

$$
\mathrm{P} \text { or } \mathrm{Tf}=\mathrm{x} / 0.0314
$$

where, the amount of rain $\mathrm{P}$ or $\mathrm{Tf}$ in $(\mathrm{mm})$ is a function of accumulated $\mathrm{x}$ (liters), divided by the catchment area in $\left(\mathrm{m}^{2}\right)$.

The quantification of the stemflow occurred with the installation of reservoirs with capacity of 60 liters in 3 trees of average DAP per plot. A 1-inch diameter, longitudinally cut hose, spirally mounted near the tree trunk, allowed the water flowing through the trunk to be stored in the reservoirs.

For the calculation of stemflow, the expression used by Preuhsler et al. (2006) was used:

$$
\mathrm{Sf}=(\mathrm{V} / \mathrm{g}) \times(\mathrm{G} / \mathrm{A})
$$

where, $\mathrm{Sf}=$ precipitation $(\mathrm{mm}), \mathrm{V}=$ volume collected (liters) $\mathrm{g}=$ tree basal area $\left(\mathrm{m}^{2}\right) \mathrm{G}=$ basal area of trees in plot $\left(\mathrm{m}^{2}\right) \mathrm{A}=$ plot area $\left(\mathrm{m}^{2}\right)$.

Volume quantification and chemical samples were collected biweekly alongo one year. At each collection the reservoirs were sterilized with a brush and distilled water.

\subsection{Chemical Determination}

The samples of incident rainfall, throughfall and stemflow were sent to the Laboratory of Forest Ecology of UFSM, which were determined $\mathrm{pH}$, with $\mathrm{pH}$ meter containing glass electrode (Metrohm $827 \mathrm{pH} \mathrm{LAB}$ ), pre-treatment with simple filtration of pores of $0.45 \mu \mathrm{m}$ for determination of $\mathrm{NO}_{2}{ }^{-}, \mathrm{NO}_{3}{ }^{-}, \mathrm{PO}_{4}{ }^{3-}, \mathrm{SO}_{4}^{-}, \mathrm{Cl}^{-}, \mathrm{K}^{+}$, $\mathrm{Ca}^{2+}$ and $\mathrm{Mg}^{2+}$ ions, by means of ion chromatography (Metrohm 861 Advanced Compac IC), all according to the methodology proposed by APHA (1998).

\subsection{Statistical Analysis}

The relation between the ions present in the solutions of the incident precipitation, throughfall and stemflow was through the Pearson correlation. For this analysis, the IBM SPSS 20.0. software was used.

The enrichment factor estimates the percentage gains of each nutriente when interacting with the tree canopy. For the calculation are used the amounts $\left(\mathrm{kg} \mathrm{ha}^{-1}\right)$ in each partition of the rain,

$$
\text { Nutrient enrichment }(\%)=\frac{(\mathrm{Tf}+\mathrm{Sf})-\mathrm{P}}{\mathrm{P}} \times 100
$$

where, Tf: throughfall; Sf: stemflow; P: incidente precipitation.

The relation between throughfall and stemflow was calculated by the incident precipitation. The amounts of each nutrient in the different partitions were used (Macinnis-Ng et al., 2012):

$$
\mathrm{E}=\mathrm{P} /(\mathrm{Tf} \text { or } \mathrm{Sf})
$$

where, E: enrichment; Tf: throughfall; Sf: stemflow; P: Precipitation.

The balance between the sum of cations and anions is important for understanding the measurements. The relationship between the two groups is expected to be unitary for quality assurance (Al Monami et al., 1995). In the present study, the results showed a unit balance of 0.9. Caggiano et al. (2014) studying the chemical composition of rainwater in western Bulgaria found a value of 1.5 indicating that some cations were excluded from the measurements. 


\section{Results and Discussion}

\subsection{Rainfall Partitioning}

The total rainfall for the evaluation period was $1903 \mathrm{~mm}$. The average interception by the crown of the trees was $8.9 \%$. The internal precipitation and trunk counts were $90.3 \%$ and $0.8 \%$, respectively. Information can be found in Momolli et al. (2019).

\subsection{Concentration of Ions}

The average $\mathrm{pH}$ was $4.57 ; 4.64$ and 5.54 for incidente, throughfall and stemflow (Figure 2). According to Charlson and Rodhe (1982), values below 5.6 may be considered acidic. It is also noted that the extent to which water flows through the leaves, branches, trunk and bark carries basic cations, thereby increasing the $\mathrm{pH}$ of the aqueous solution.

The results show that the canopy have the capacity to neutralization the $\mathrm{pH}$ of the solution as it interacts with the canopy of the stand. Crockford, Richardson, and Sageman (1996) found pH of 5.66 and 5.30 for throughfall and incident precipitation respectively. According to Miller (1984) these results also suggest the absorption of hydrogen ions by the surface of the vegetation neutralizing the $\mathrm{pH}$ of water. Other studies have confirmed the tendency to increase $\mathrm{pH}$ as is the case of Shiklomanov and Levia (2014) studying the neutralization capacity of the stemflow in the stand of Liriodendron tulipifera at 19 years of age in Maryland USA.

Evaluating the $\mathrm{pH}$ in Eucalyptus dunnii stands from 5 to 6 years of age, Dick et al. (2018) showed that the pH was $4.3 ; 5.0$ and 5.3 for incident precipitation, throughfall and stemflow respectively. Correa (2011) also studying a stand of Eucalyptus dunnii from 1.4 to 2.4 years of age found the following pH values: 5.0; 5.2 and 5.3 for incident precipitation, throughfall and stemflow respectively.

The order of the contents of the ions in the rainfall precipitation incident was: $\mathrm{SO}_{4}{ }^{2-}>\mathrm{Ca}^{2+}>\mathrm{Cl}^{-}>\mathrm{K}^{+}>\mathrm{Mg}^{2+}>$ $\mathrm{NO}_{3}{ }^{-}>\mathrm{NO}_{2}{ }^{-}>\mathrm{PO}_{4}{ }^{3-}$. In the throughfall: $\mathrm{Cl}^{-}>\mathrm{K}^{+}>\mathrm{Ca}^{2+}>\mathrm{SO}_{4}{ }^{2-}>\mathrm{Mg}^{2+}>\mathrm{NO}_{3}{ }^{-}>\mathrm{NO}_{2}{ }^{-}>\mathrm{PO}_{4}{ }^{3-}$. Stemflow: $\mathrm{K}^{+}>$ $\mathrm{Cl}^{-}>\mathrm{Mg}^{2+}>\mathrm{Ca}^{2+}>\mathrm{SO}_{4}{ }^{2-}>\mathrm{PO}_{4}{ }^{3-}>\mathrm{NO}_{2}^{-}>\mathrm{NO}_{3}^{-}$. 

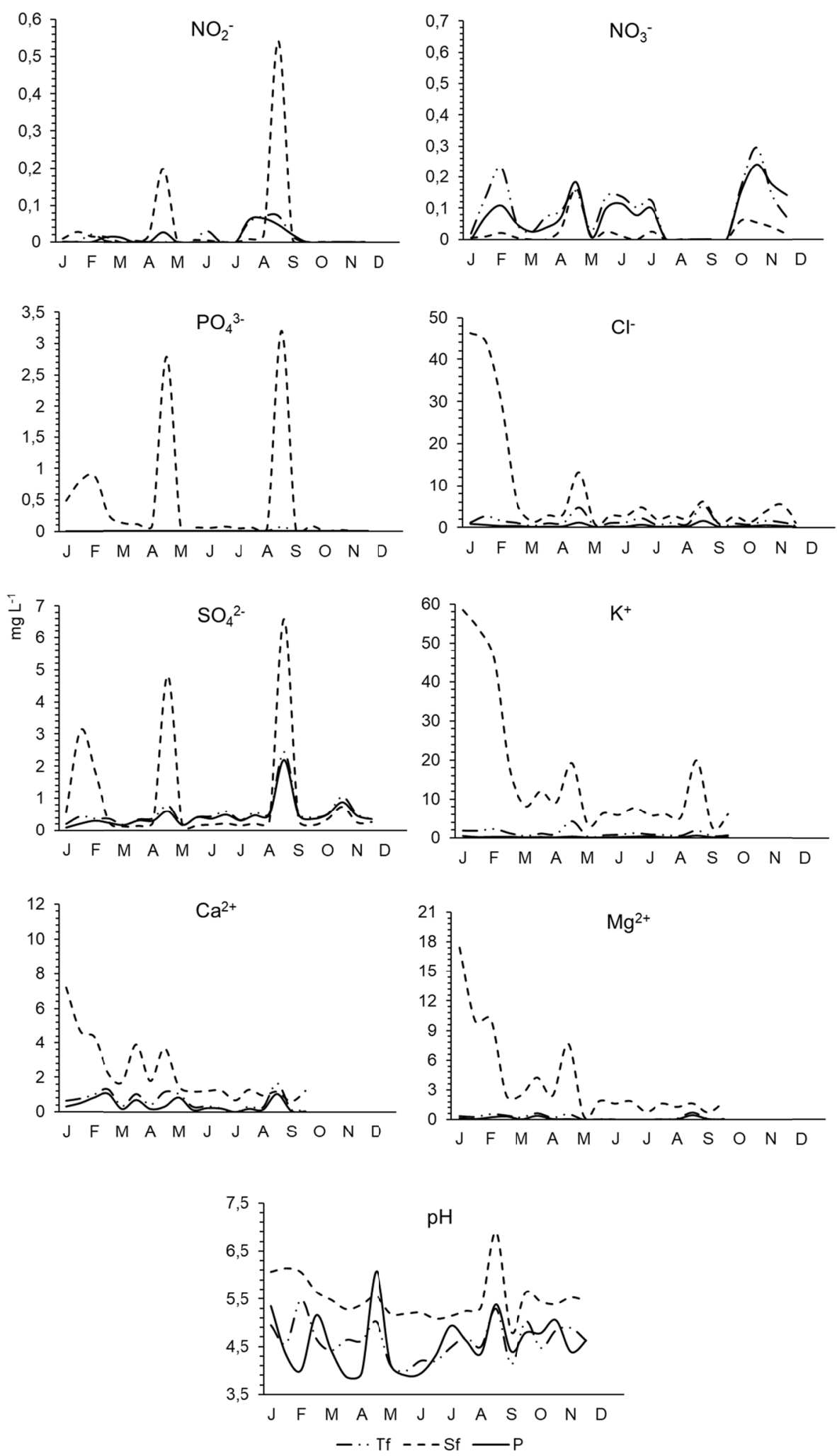

Figure 2. Concentration of the Ions $\left(\mathrm{mg} \mathrm{L}^{-1}\right)$ and $\mathrm{pH}$, for Incident precipitation (P), throughfall (Tf) and stemflow (Sf)

After interaction with the canopy, all the ions presented increase in the contents. In general, the contents of the stemflow solution were more expressive mainly because of the low volume of water. The mean $\mathrm{K}^{+}$contents were: 
$0.20 ; 1.28$ and $17.55 \mathrm{mg} \mathrm{L}^{-1}$ for $\mathrm{P}$, Tf and $\mathrm{Sf} \mathrm{Cl}^{-}$also recorded a significant increase: $0.41 ; 1.5$ and $11.14 \mathrm{mg} \mathrm{L}^{-1}$ for $\mathrm{P}, \mathrm{Tf}$ and $\mathrm{Sf}$.

The calcium contents were $0.42 ; 0.71$ and 2.73 for P, Tf and Sf. Although Valente et al. (2016) found higher levels of the element in P than in Tf, Cornu et al. (1998) suggested that the washing of exudates from the decomposition of branches contributed to the increase in $\mathrm{Tf}$.

$\mathrm{Mg}^{2+}$ and $\mathrm{Ca}^{2+}$ ions had a Pearson correlation of: $0.91 ; 0.89$ and 0.57 for incident precipitation, throughfall and stemflow respectively (Table 1). Salve et al. (2008) evaluating the chemical composition of rainwater in Maharashtra in India found $r=0.95$. The authors suggest that this high correlation is due to the occurrence of crustal origin.

Pearson's correlation also shows the inverse relation between the pluviometric indexes and the ion concentration. This finding can also be observed in other studies such as Valente et al. (2016) quantifying the nutrient input in Eucalyptus urophylla $\times$ Eucalyptus globulus stands. According to Laclau et al. (2003) this can be explained by the effect of dilution of the ions as precipitation increases.

Table 1. Pearson correlation analysis between ions in the incident precipitation (P), throughfall (Tf) and stemflow (Sf) in Eucalyptus stands dunnii

\begin{tabular}{|c|c|c|c|c|c|c|c|c|c|c|}
\hline & $\mathrm{P}_{(\mathrm{mm})}$ & $\mathrm{pH}$ & $\mathrm{NO}_{2}^{-}$ & $\mathrm{NO}_{3}^{-}$ & $\mathrm{PO}_{4}{ }^{3-}$ & $\mathrm{Cl}^{-}$ & $\mathrm{SO}_{4}{ }^{2-}$ & $\mathrm{K}^{+}$ & $\mathrm{Mg}^{2+}$ & $\mathrm{Ca}^{2+}$ \\
\hline $\mathrm{P}_{(\mathrm{mm})}$ & 1 & & & & & & & & & \\
\hline $\mathrm{pH}$ & -0.27 & 1 & & & & & & & & \\
\hline $\mathrm{NO}_{2}^{-}$ & -0.31 & $0.98^{* * *}$ & 1 & & & & & & & \\
\hline $\mathrm{NO}_{3}^{-}$ & -0.36 & -0.17 & -0.01 & 1 & & & & & & \\
\hline $\mathrm{PO}_{4}^{3-}$ & -0.28 & -0.11 & 0.06 & $0.95^{* * *}$ & 1 & & & & & \\
\hline $\mathrm{Cl}^{-}$ & -0.42 & -0.18 & -0.03 & $0.89^{* * *}$ & $0.91^{* * *}$ & 1 & & & & \\
\hline $\mathrm{SO}_{4}^{2-}$ & -0.27 & -0.08 & -0.12 & -0.23 & -0.21 & 0.09 & 1 & & & \\
\hline $\mathrm{K}^{+}$ & 0.00 & -0.04 & -0.06 & 0.08 & -0.05 & -0.07 & 0.05 & 1 & & \\
\hline $\mathrm{Mg}^{2+}$ & -0.28 & $1.00^{* * *}$ & $0.99^{* * *}$ & -0.11 & -0.05 & -0.14 & -0.11 & -0.03 & 1 & \\
\hline \multirow[t]{2}{*}{$\mathrm{Ca}^{2+}$} & -0.26 & $0.91^{* * *}$ & $0.90^{* * *}$ & -0.14 & -0.05 & -0.07 & 0.03 & -0.15 & $0.91^{* * *}$ & 1 \\
\hline & $\mathrm{Tf}_{(\mathrm{mm})}$ & $\mathrm{pH}$ & $\mathrm{NO}_{2}^{-}$ & $\mathrm{NO}_{3}^{-}$ & $\mathrm{PO}_{4}^{3-}$ & $\mathrm{Cl}^{-}$ & $\mathrm{SO}_{4}{ }^{2-}$ & $\mathrm{K}^{+}$ & $\mathrm{Mg}^{2+}$ & $\mathrm{Ca}^{2+}$ \\
\hline $\mathrm{Tf}_{(\mathrm{mm})}$ & 1 & & & & & & & & & \\
\hline $\mathrm{pH}$ & -0.26 & 1 & & & & & & & & \\
\hline $\mathrm{NO}_{2}^{-}$ & -0.35 & $0.92^{* * *}$ & 1 & & & & & & & \\
\hline $\mathrm{NO}_{3}^{-}$ & -0.36 & -0.19 & 0.19 & 1 & & & & & & \\
\hline $\mathrm{PO}_{4}^{3-}$ & -0.27 & -0.12 & 0.27 & $0.95^{* * *}$ & 1 & & & & & \\
\hline $\mathrm{Cl}^{-}$ & $-0.54^{*}$ & -0.26 & -0.06 & $0.52^{*}$ & $0.50^{*}$ & 1 & & & & \\
\hline $\mathrm{SO}_{4}^{2-}$ & -0.32 & 0.03 & -0.06 & -0.28 & -0.24 & $0.52^{*}$ & 1 & & & \\
\hline $\mathrm{K}^{+}$ & -0.04 & -0.05 & -0.08 & 0.05 & -0.06 & -0.11 & 0.02 & 1 & & \\
\hline $\mathrm{Mg}^{2+}$ & -0.27 & $1.00^{* * *}$ & $0.95^{* * *}$ & -0.12 & -0.05 & -0.24 & 0.01 & -0.03 & 1 & \\
\hline \multirow[t]{2}{*}{$\mathrm{Ca}^{2+}$} & -0.34 & $0.89^{* * *}$ & $0.89^{* * *}$ & 0.01 & 0.08 & 0.08 & 0.18 & -0.18 & $0.89^{* * *}$ & 1 \\
\hline & $\mathrm{Sf}_{(\mathrm{mm})}$ & $\mathrm{pH}$ & $\mathrm{NO}_{2}^{-}$ & $\mathrm{NO}_{3}^{-}$ & $\mathrm{PO}_{4}^{3-}$ & $\mathrm{Cl}^{-}$ & $\mathrm{SO}_{4}{ }^{2-}$ & $\mathrm{K}^{+}$ & $\mathrm{Mg}^{2+}$ & $\mathrm{Ca}^{2+}$ \\
\hline$S f_{(\mathrm{mm})}$ & 1 & & & & & & & & & \\
\hline $\mathrm{pH}$ & 0.15 & 1 & & & & & & & & \\
\hline $\mathrm{NO}_{2}^{-}$ & -0.30 & $-0.91^{* * *}$ & 1 & & & & & & & \\
\hline $\mathrm{NO}_{3}^{-}$ & -0.32 & $-0.67^{* * *}$ & $0.51^{*}$ & 1 & & & & & & \\
\hline $\mathrm{PO}_{4}^{3-}$ & $-0.47^{*}$ & 0.26 & -0.01 & 0.13 & 1 & & & & & \\
\hline $\mathrm{Cl}^{-}$ & -0.34 & 0.29 & -0.15 & -0.04 & 0.26 & 1 & & & & \\
\hline $\mathrm{SO}_{4}^{2-}$ & $-0.48^{*}$ & 0.29 & 0.03 & -0.04 & $0.95^{* * *}$ & 0.31 & 1 & & & \\
\hline $\mathrm{K}^{+}$ & -0.31 & $0.44^{*}$ & -0.25 & -0.18 & 0.34 & $0.97^{* * *}$ & 0.39 & 1 & & \\
\hline $\mathrm{Mg}^{2+}$ & -0.30 & 0.35 & -0.21 & -0.14 & 0.24 & 0.91 & 0.25 & $0.90^{* * *}$ & 1 & \\
\hline $\mathrm{Ca}^{2+}$ & -0.42 & $-0.45^{*}$ & $0.60^{* *}$ & 0.31 & 0.14 & $0.59^{* *}$ & 0.15 & $0.53^{*}$ & $0.57^{* *}$ & 1 \\
\hline
\end{tabular}

Note. Level of significance: ${ }^{*}: \mathrm{p}<0.05 ;{ }^{* *}: \mathrm{p}<0.01 ;{ }^{* * *}: \mathrm{p}<0.001$. 
The $\mathrm{pH}$ had a correlation of 1.00 and 0.89 with the $\mathrm{Mg}^{2+}$ and $\mathrm{Ca}^{2+}$ ions in the throughfall. These findings suggest that the leaching of plant tissues, when carrying basic cations, becomes responsible for neutralizing the $\mathrm{pH}$ from the incident precipitation.

\subsection{Nutrients Input}

The total amount of ions was 29.5; 67.6 and $10.0 \mathrm{~kg} \mathrm{ha}^{-1}$ for incident precipitation, throughfall and stemflow respectively. The difference between the net precipitation by the incident precipitation $((\mathrm{Tf}+\mathrm{Sf})-\mathrm{P})$ was 42.8 $\mathrm{kg} \mathrm{ha}^{-1}$, which in turn represented an enrichment of $163.5 \%$ of the total amount of ions contributed after interaction with the stands.

The total amount contributed by the net precipitation was $77.6 \mathrm{~kg} \mathrm{ha}^{-1}$, of which, $64.7 \%$ were $\mathrm{Cl}^{-}+\mathrm{K}^{+}$(Figure 3). The difference of $\mathrm{K}^{+} \mathrm{d}$ the net precipitation by the incident precipitation shows an increase of $18.8 \mathrm{~kg} \mathrm{ha}^{-1}$, that is, $607 \%$ enrichment. The same behavior was observed for $\mathrm{Mg}^{2+}$ and $\mathrm{Cl}^{-}$, in which the interaction with the canopy was responsible for the enrichment in 155 and $276 \%$ respectively.

The input of $7.5 \mathrm{~kg} \mathrm{ha}^{-1}$ of chlorine in the incident precipitation is similar to that found by Dick et al. (2018) who quantified an average of $6.5 \mathrm{~kg} \mathrm{ha}^{-1}$ for two years of evaluation. However, Valente et al. (2016) quantified a contribution of $49.4 \mathrm{~kg} \mathrm{ha}^{-1}$, and the experiment was $170 \mathrm{~km}$ away from the ocean. For Loss et al. (2010) as it moves away from the ocean towards the interior of the continent, the proportion of $\mathrm{Cl}^{-}$decreases. Sodium chloride has its source from the evaporation of ocean water and enters the continent by means of marine spray. The present study is $400 \mathrm{~km}$ away straight from the ocean.

In relation to the expressive increase of chlorine in the internal precipitation, Prado (2008) points out that the element has high mobility in the plant, being constituent of the photosynthesis and therefore easily leached from the plant structures.

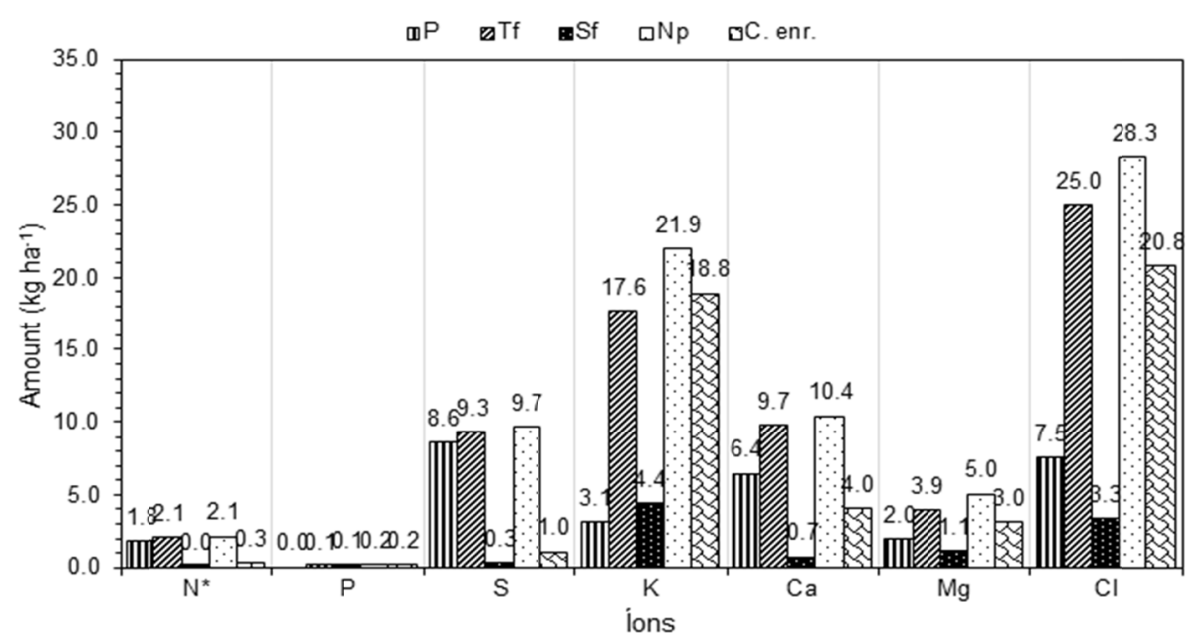

Figure 3. Nutrients input $\left(\mathrm{kg} \mathrm{ha}^{-1}\right)$ for incident rainfall (P), throughfall (Tf), stemflow (Sf) and net precipitation $(\mathrm{Pl})$

Note. $\mathrm{N}^{*}=\mathrm{NO}_{2}^{-}+\mathrm{NO}_{3}^{-}$.

On average, $46.2 \%$ of the nutrients come from the incident precipitation and $53.8 \%$ from the interaction with the biomass (Table 2). It is also observed that 61.7 and $89.2 \%$ of $\mathrm{Ca}^{2+}$ and $\mathrm{SO}_{4}{ }^{2-}$, are derived from the incident precipitation. The Sf represents only $0.8 \%$ of the solution volume, however, when we consider the concentration of ions becomes more representative, reaching 12.8\%. According Gay and Murphy (1985) approximately 30-70\% of the total dry deposited $\mathrm{SO}_{4}{ }^{2-}$ may be retained in the canopy.

Calil et al. (2010) found an entry for nutrients incident rainfall $102.1 \mathrm{~kg} \mathrm{ha}^{-1}$, of these, about $40 \%$ of $^{2} \mathrm{SO}_{4}{ }^{2-}$. In the present study, the total was only $29.5 \mathrm{~kg} \mathrm{ha}^{-1}$, of these, $29.2 \% \mathrm{SO}_{4}{ }^{2-}$. The higher amount of $\mathrm{SO}_{4}{ }^{2-}$ by Calil et al. (2010) whether the existence of pollutant emissions by burning coal in thermoelectric Candiota. According to Rótulo (2003), the plant did not have a suitable filter system, which caused the high emission of $\mathrm{SO}_{4}{ }^{2-}$. 
Table 2. Percentage of chemical elements in incident precipitation $(\mathrm{P})$, throughfall $(\mathrm{Tf})$, stemflow (Sf) and nutriente enrichment after canopy interaction

\begin{tabular}{|c|c|c|c|c|c|c|}
\hline Partition & $\mathrm{K}^{+}$ & $\mathrm{Ca}^{2+}$ & $\mathrm{Mg}^{2+}$ & $\mathrm{SO}_{4}^{2-}$ & $\mathrm{Cl}^{-}$ & Average \\
\hline & ----- & 47 & -1--- & - & $a r$ & \\
\hline P & 14.1 & 61.7 & 39.1 & 89.2 & 26.6 & 46.2 \\
\hline Tf & 68.8 & 35.8 & 47.3 & 10.3 & 64.7 & 45.4 \\
\hline Sf & 17.1 & 2.5 & 13.6 & 0.5 & 8.7 & 8.45 \\
\hline Total & 100 & & & & & \\
\hline $\mathrm{Tf}+\mathrm{Sf}$ & 85.9 & 38.3 & 60.9 & 10.8 & 73.4 & 53.8 \\
\hline & --- & 025 & -1 & p ----- & - & - \\
\hline Tf & 80.1 & 93.5 & 77.6 & 96.7 & 88.2 & 87.2 \\
\hline Sf & 19.9 & 6.5 & 22.4 & 3.3 & 11.8 & 12.8 \\
\hline Total & 100 & & & & & \\
\hline Nutrient enrichment & 607.1 & 62.0 & 155.5 & 12.1 & 275.8 & 222.5 \\
\hline
\end{tabular}

Migliavacca et al. (2005) in a study developed in the region of Candiota found slightly acid pH indexes 4.0-5.6. The factorial analysis also showed a possible contribution of marine salts influencing the contents of $\mathrm{Cl}^{-}$and $\mathrm{Mg}^{2+}$. The analysis also indicated anthropogenic influences mainly for $\mathrm{SO}_{4}{ }^{2-}$ and $\mathrm{K}^{+}$ions. In our study, the mean $\mathrm{pH}$ was 4.5; 4.7 and 5.6 for incident, throughfall and stemflow, indicating mild acidity.

A prediction model was presented during CLRTAP, the Gothenburg Protocol (Fagerli et al., 2006), showed that in 1990 several areas of Europe had S deposition higher than $30 \mathrm{~kg} \mathrm{ha}^{-1}$. In 2004, only part of Europe had deposition higher than $10 \mathrm{~kg} \mathrm{ha}^{-1}$. These results are relevant to the reduction of particulate emissions by the best efficiency of the filters, therefore, for the study developed by Calil et al. (2010), the quantities were above average.

Rainwater when interacting with the canopy is enriched mainly with $\mathrm{K}^{+}, \mathrm{Mg}^{2+}$ and $\mathrm{Cl}^{-}$. In Table 3 the $\mathrm{Tf} / \mathrm{P}$ (throughfall/precipitation) and $\mathrm{Sf} / \mathrm{P}$ ratio (stemflow/precipitation) is compared for the ion concentrations found in the present study with those of other works. Relationships $>1$, indicate that there is an increase in contents after passage through the canopy. $\mathrm{Cl}^{-}$and $\mathrm{Ca}^{2+}$ presented the lowest relationships for throughfall. Sulfate $\left(\mathrm{SO}_{4}{ }^{2-}\right)$ is formed after the absorption of $\mathrm{SO}_{4}{ }^{2-}$ by clouds or raindrops, followed by oxidation in aqueous phase (Vujović \& Milić-Petrović, 2016), which explains the lower levels. For Laclau et al. (2003) and Laclau et al. (2010) values <1 were observed for $\mathrm{Ca}^{2+}$ in the throughfall.

Table 3. Relation of the concentrations of the precipitation incident with the throughfall (Tf) and stemflow (Sf) with other studies

\begin{tabular}{|c|c|c|c|c|c|c|c|}
\hline & $\mathrm{K}^{+}$ & $\mathrm{Ca}^{2+}$ & $\mathrm{Mg}^{2+}$ & $\mathrm{SO}_{4}{ }^{2-}$ & $\mathrm{Cl}^{-}$ & Author & Specie \\
\hline Tf & 3.70 & 1.21 & 6.33 & 2.21 & 1.69 & \multirow{2}{*}{ Present study } & \multirow{2}{*}{ Eucalyptus dunnii } \\
\hline Sf & 27.40 & 2.30 & 86.56 & 35.24 & 6.49 & & \\
\hline Tf & 2.80 & 0.99 & 3.30 & 1.24 & 1.38 & \multirow{4}{*}{ Laclau et al. (2003) } & \multirow{3}{*}{ Eucalyptus (Rainy season) } \\
\hline Sf & 10.48 & 2.09 & 21.31 & 3.29 & 6.28 & & \\
\hline Tf & 1.46 & 1.14 & 1.85 & 1.48 & 1.04 & & \\
\hline Sf & 1.64 & 1.05 & 6.84 & 1.11 & 1.95 & & Eucalyptus (Dry season) \\
\hline Tf & 4.21 & 1.50 & 2.46 & - & - & \multirow{2}{*}{ Balieiro et al. (2007) } & \multirow{2}{*}{ Eucalyptus grandis } \\
\hline Sf & 25.71 & 18.75 & 18.21 & - & - & & \\
\hline Tf & 6.89 & 1.43 & 2.38 & 1.09 & 3.96 & \multirow{2}{*}{ Corrêa (2011) } & \multirow{2}{*}{ Eucalyptus dunnii } \\
\hline Sf & 39.11 & 5.09 & 8.50 & 1.00 & 14.17 & & \\
\hline $\mathrm{Tf}$ & 24.36 & 11.25 & 5.83 & - & - & \multirow{2}{*}{ Dezzeo and Chacón (2006) } & \multirow{2}{*}{ Primary Forest } \\
\hline Sf & 42.36 & 17.00 & 5.33 & - & - & & \\
\hline Tf & 6.38 & 1.30 & 1.57 & 1.43 & 1.19 & \multirow{2}{*}{ Caggiano et al. (2014) } & \multirow{2}{*}{ Fagus sylvatica } \\
\hline $\mathrm{Sf}$ & 8.12 & 2.70 & 2.83 & 3.33 & 1.87 & & \\
\hline Tf & 4.42 & 2.11 & 2.34 & 2.55 & 1.47 & \multirow{2}{*}{ Caggiano et al. (2014) } & \multirow{2}{*}{ Picea abies } \\
\hline $\mathrm{Sf}$ & 8.89 & 5.65 & 5.34 & 8.29 & 2.33 & & \\
\hline $\mathrm{Tf}$ & 5.22 & 1.46 & 3.28 & 1.51 & 1.84 & \multirow{2}{*}{ Dick et al. (2018) } & \multirow{2}{*}{ Eucalyptus dunnii } \\
\hline Sf & 38.43 & 1.74 & 19.00 & 0.92 & 7.79 & & \\
\hline Tf & 12.85 & 2.15 & 1.65 & 1.98 & 1.44 & Heartsill-Scalley et al. (2007) & Subtropical Forest \\
\hline $\mathrm{Tf}$ & 3.58 & - & - & - & - & \multirow{2}{*}{ Perez-Marin and Menezes (2008) } & \multirow{2}{*}{ Gliricidia sepium } \\
\hline Sf & 6.46 & - & - & - & - & & \\
\hline
\end{tabular}


Laclau et al. (2010) evaluating chlorine + potassium in the throughfall and stemflow found 7.0 and $5.8 \mathrm{~kg} \mathrm{ha}^{-1}$ in Itatinga-Brazil and Kondi-Congo respectively. In the present study the quantities were much higher than $31.5 \mathrm{~kg}$ ha ${ }^{-1}$ for Tf + Sf. Salehi et al. (2016) found more approximate values, $36.3 \mathrm{~kg} \mathrm{ha}^{-1}$.

The chemical alteration of the throughfall is due to leaching of the plant structures (leaves, bark, etc.), together with the dissolution of aerosols and particles deposited on the forest canopy (Lindberg \& Lovett, 1985; Laclau et al., 2003). Salehi et al. (2016) also showed that the canopy composition in stands of eastern Phage had great influence on the nutrient flow of Tf. Caggiano et al. (2014) found an increase in $\mathrm{K}^{+}$levels in the Tf: 572 and $486 \%$ for Fagus sylvatica L. and Spruce abies L., relative to the incident precipitation.

Calil et al. (2010) studied the precipitation via nutrient inputs in the southeast of Rio Grande do Sul. The average rainfall of the two years evaluated was $1588 \mathrm{~mm}$, about $12 \%$ higher than the historical average for the region. Pearson's correlation to the authors showed that when the rainfall volumes are higher, the average concentrations of ions decrease considerably (negative correlation). This behavior was observed in our study and is related to the dilution effect of deposited and suspended particles.

\section{Conclusions}

Although it represents $0.8 \%$ of the volume of solution of the precipitation incidente, the stemflow represents an important source of nutrients to soil $12.8 \%$. The $\mathrm{pH}$ of the incident precipitation and throughfall is influenced by $\mathrm{Ca}^{2+}$ and $\mathrm{Mg}^{2+}$ cations and by $\mathrm{NO}_{2}^{-}$. The forest canopy is able to neutralize the $\mathrm{pH}$ of the incident precipitation through the absorption of $\mathrm{H}$ ions and leaching of basic cations present in the cellular structures.

The total nutrient input by the precipitation after interaction with the canopy was 2.6 times higher when compared to the open area entrances.

The input of $\mathrm{N}$ and $\mathrm{K}$ via incident rainfall was 1.8 and $3.1 \mathrm{~kg} \mathrm{ha}^{-1}$. Considering the fertilization described in the methodology, this contributed amount represents 6.1 and $2.6 \%$ of the total. If we consider the rotation of 7 years for Eucalyptus dunnii, the contribution at the end of rotation represents 42.4 and $18 \%$ of $\mathrm{N}_{\text {and }} \mathrm{K}_{2} \mathrm{O}$. Through these results we can infer about the management of fertilization allowing the reduction of the applied amounts of fertilizers. With this, there is a reduction of the costs of fertilization, labor, and benefits to the environment with the reduction of the risks of contamination of the water table.

\section{References}

AGRITEMPO. (2019). Dados meteorológicos-Alegrete. Campinas. Retrieved from http://www.agritempo.gov.br

Al-Momani, I. F., Tuncel, S., Eler, U., O” rtel, E., Sirin, D., \& Tuncel, G. (1995). Major ion composition of wet and dry deposition in the eastern Mediterranean basin. Sci Total Environ, 164, 75-85. https://doi.org/ 10.1016/0048-9697(95)04468-G

Alvares, C. A., Stape, J. L., Sentelhas, P. C., Gonçalves, J. L. M., \& Sparovek, G. (2014). Köppen’s climate classification map for Brazil. Meteorologische Zeitschrift, 22(6), 711-728. https://doi.org/10.1127/09412948/2013/0507

Andre, F., Jonard, M., \& Ponette, Q. (2008). Effects of biological and meteorological factors on stemflow chemistry within a temperate mixed oak-beech stand. Science of the Total Environment, 393, 72-83. https://doi.org/10.1016/j.scitotenv.2007.12.002

APHA (American Public Health Association). (1998). Standard methods for the examination of water and wastewater (19th ed.). American Public Health Association, American Water Works Association, Water Pollution Control Federation, Washington, D.C.

Balieiro, F. C., Franco, A. A., Fontes, R. L. F., Dias, L. E., Campello, E. F. C., \& Faria, S. M. (2007). Evaluation of the throughfall stemflow nutrient contents in mixed and pure plantations of Acacia mangium, Pseudosamenea guachapele and Eucalyptus grandis. Revista Árvore, 31(2), 339-346. https://doi.org/ $10.1590 / \mathrm{S} 0100-67622007000200017$

Bhat, S., Jacobs, J., \& Bryant, M. (2011). The chemical composition of rainfall and throughfall in five forest communities: A case study in Fort Benning, Georgia. Water, Air, \& Soil Pollution, 218, 323-332. https://doi.org/10.1007/s11270-010-0644-1

Brasil. (2016). Ministério do Meio Ambiente, Bioma, Pampa. Retrieved from http://www.mma.gov.br/biomas/ pampa

Caggiano, R., Fikova, R., Trippetta, S., Bratanova-Doncheva, S., Ignatova, N., \& Telesca, L. (2014). An assessment of rainfall modification in mountainous ecosystems dominated by Fagus sylvatica L. and Picea 
abies (L.) Karst. (Western Balkans, Bulgaria) by multivariate analyses. European Journal of Forest Research, 133(4), 699-711. https://doi.org/10.1007/s10342-013-0713-2

Calil, F. N., Schumacher, M. V., Witschoreck, R., Lopes, V. G., Viera, M., \& Liberalesso, E. (2010). Ion input via rainwater in the southern region of Rio Grande do Sul, Brazil. Cerne, 16(3), 373-380. https://doi.org/ $10.1590 / \mathrm{S} 0104-77602010000300013$

Charlson, R. J., \& Rodhe, H. (1982). Factors controlling the acidity of natural rainwater. Nature, 295, 683-685. https://doi.org/10.1038/295683a0

Corrêa, R. S. (2011). Ciclagem de nutrientes em Eucalypts dunnii estabelecido no Bioma Pampa (99f., Tese (Doutorado em Engenharia Florestal), Universidade Federal de Santa Maria, Santa Maria, RS).

Cornu, S., Ambrosi, J. P., Lucas, Y., \& Desjardins, T. (1998). Origin and behavior of dissolved chlrorine and sodium in Brazilian Rainforest. Water Research, London, 32(4), 1151-1161. https://doi.org/10.1016/ S0043-1354(97)00298-4

Crockford, R. H., Richardson, D. P., \& Sageman, R. (1996). Chemistry of rainfall, throughfall and stemflow in a eucalypt forest and a pine plantation in south-eastern Australia: 2. Throughfall. Hydrological Processes, 10(1), 13-24. https://doi.org/10.1002/(SICI)1099-1085(199601)10:1<13::AID-HYP296>3.0.CO;2-5

Dezzeo, N., \& Chacón, N. (2006). Nutrient fluxes in incident rainfall, throughfall, and stemflow in adjacent primary and secondary forests of the Gran Sabana, Southern Venezuela. Forest Ecology and Management, 234, 218-226. https://doi.org/10.1016/j.foreco.2006.07.003

Dick, G., Schumacher, M. V., Momolli, D. R., \& Viera, M. (2018) Nutrient input via incident rainfall in a Eucalyptus dunnii stand in the Pama Biome. Floresta e Ambiente, Seropédica, 25(3).

Dixon, A. P., Faber-Langendoen, D., Josse, C., Loucks, C. J., \& Morrison, J. (2014). Distribution mapping of world grassland types. J. Biogeogr. https://doi.org/10.1111/jbi.12381

Eaton, J. S., Likens, G. E., \& Bormann, F. H. (1973). Throughfall and stemflow chemistry in a northern hardwood forest. Journal Ecology, 61(2), 495-508. https://doi.org/10.2307/2259041

Fagerli, H., Spranger, T., \& Posch, M., (2006). Chapter 3: Acidification and eutrophication e progress towards the Gothenburg protocol target year 2010. Transboundary Acidification, Eutrophication and Ground Level Ozone in Europe since 1990 to 2004 (EMEP Status Report 1/06). Norwegian Meteorological Institute, Oslo. Retrieved from http://emep.int/publ/reports/2006/status_report_1_2006_ch.pdf

FAO. (2015). Global forest resources assessment FRA How are the world's forests changing? (p. 46). Rome, Italy. Retrieved from http://www.fao.org/3/a-i4793e.pdf

Flores, T. B., Alvares C. A., Souza V. C., \& Stape J. L. (2016). Eucalyptus no Brasil: Zoneamento climático e guia para identificação. Piracicaba: IPEF.

Gay, D. W., \& Murphy, C. E. (1985). The Deposition of $\mathrm{SO}_{4}^{2-}$ on Forests (Final Report, EPRI Project R.P. 1813-2). Electric Power Research Institute, Palo Alto, CA.

Heartsill-Scalley, T., Scatena, F. N., Estrada, C., McDowell, W. H., \& Lugo, A. E. (2007). Disturbance and long-term patterns of rainfall and throughfall nutrient fluxes in a subtropical wet forest in Puerto Rico. Journal of Hydrology, 333(2-4), 472-485. https://doi.org/10.1016/j.jhydrol.2006.09.019

Jung, K., Chang, S. X., \& Arshad, M. A. (2011). Effects of canopy deposition interaction on $\mathrm{H}^{+}$supply to soils in Pinus banksiana and Populus tremuloides ecosystems in the Athabasca oil sands region in Alberta, Canada. Environmental Pollution, 159, 1327-1333. https://doi.org/10.1016/j.envpol.2011.01.012

Laclau, J. P. (2010). Biogeochemical cycles of nutrients in tropical Eucalyptus plantations Main features shown by intensive monitoring in Congo and Brazil. Forest Ecology and Management, 259, 1771-1785. https://doi.org/10.1016/j.foreco.2009.06.010

Laclau, J. P., Ranger, J., Bouillet, J. P., Nzila, J. D., \& Deleporte, P. (2003). Nutrient cycling in a clonal stand of Eucalyptus and an adjacent savanna ecosystem in Congo 1. Chemical composition of rainfall, throughfall and stemflow solutions. Forest Ecology and Management, 176, 105-119. https://doi.org/10.1016/S03781127(02)00280-3

Levia D. F., Keim, R. F., Carlyle-Moses, D. E., \& Frost, E. E. (2011). Throughfall and stemflow in wooded ecosystems. Forest Hydrology and Biogeochemistry: Synthesis of Past Research and Future Directions (Ecological Series 216). Springer-Verlag: Heidelberg, Germany. https://doi.org/10.1007/978-94-007-1363-5 
Lima, W. P. (1976). Interceptação da chuva em povoamento de eucalipto e de pinheiro. IPEF, 13, 75-90.

Lindberg, S. E., \& Lovett, G. M. (1985). Field measurements of particle dry deposition rates to foliage and inert surfaces in a forest canopy. Environmental Science \& Technology, 19(3), 228-244. https://doi.org/10.1021/ es00133a003

Loss, A., Rossi, C. Q., \& Francelino, M. R. (2010). A origem da salinidade no Continente Antártico. Revista de Ciências Agrárias, 33(2), 106-117.

Macinnis-Ng, C. M. O., Flores, E. E., Müller, H., \& Schwendenmann, L. (2012). Rainfall partitioning into throughfall and stemflow and associated nutrient fluxes: Land use impacts in a lower montane tropical region of Panama. Biogeochemistry, 111(661). https://doi.org/10.1007/s10533-012-9709-0

Migliavacca, D. M., Teixeira, E. C., Machado, A. C. M., \& Pires, M. R. (2005). Composição química da precipitação atmosférica no sul do Brasil-Estudo preliminar. Quimica Nova, 28(3), 371-379. https://doi.org/ 10.1590/S0100-40422005000300002

Miller, H. H., Unsworth, M. H., Rosenqvist, I. T., Abrahamsen, G., Beament, J. W. L., Bradshaw, A. D., ... Thrush, B. A. (1984). Deposition-plant-soil interactions. Philosophical Transactions Royal Society, 305, 339-352. https://doi.org/10.1098/rstb.1984.0062

Momolli, D. R., Schumacher, M. V., Viera, M, Ludvichak, A. A., Guimarães, C. C., \& Souza, H. P. (2019). Incident precipitation partitioning: throughfall, stemflow and canopy interception in Eucalyptus dunnii stand. Journal of Agricultural Science, 11(5).

Navar, J., Gonzalez, J. M., \& Gonzalez, H. (2009). Gross precipitation and throughfall chemistry in legume species planted in Northeastern Mexico. Plant Soil, 318, 15-26. https://doi.org/10.1007/s11104-0089812-0

Neary, A. J., \& Gizyn, W. I. (1994). Throughfall and stemflow chemistry under deciduous and coniferous forest canopies in south-central Ontario. Can. J. For. Res, 24, 1089-1100. https://doi.org/10.1139/x94-145

Nunes, J., Madeira, M., \& Gazarini, L. (2003). Fluxos de nutrientes em árvores de montado de Quercus rotundifolia Lam., no Sul de Portugal. Revista de Ciências Agrárias, 28, 328-342.

Parker, G. G. (1983). Throughfall and stemflow in the forest nutriente cycle. Advances in Ecological Research, 13, 57-120. https://doi.org/10.1016/S0065-2504(08)60108-7

Pereira, E., Madeira, M., \& Abreu, F. G. (2009). Concentrações e fluxos de nutrientes no gotejo e escorrimento do tronco de Fraxinus angustifolia Vahl. Revista de Ciências Agrárias, 32(2), 123-134.

Perez-Marin, A. M., \& Menezes, R. S. C. (2008). Ciclagem de nutrientes via precipitação pluvial total, interna e escoamento pelo tronco em sistema agroflorestal com Gliricidia sepium. Revista Brasileira de Ciência do Solo, 32(6), 2573-2579. https://doi.org/10.1590/S0100-06832008000600034

Prado, R. M. (2008). Nutrição de plantas (p. 407). São Paulo: Editora UNESP.

Preuhsler, T., Bastrup-Birk, A., \& Beuker, E. (2006). Manual on methods and criteria for harmonized sampling, assessment, monitoring and analysis of the effects of air pollution on forests. Part VII: Meteorological Measurements.

Rótulo, D. (2003). Negociação e Implementação de Acordos de Poluição Transfronteiriça: O Caso Brasil-Uruguai em Relação à Termelétrica de Candiota (RS) (Tese (Doutorado em Administração), Fundação Getúlio Vargas, Rio de Janeiro).

Salehi, M., Zahedi Amiri, G., \& Attarod, P. (2016). Seasonal variations of throughfall chemistry in pure and mixed stands of Oriental beech (Fagus orientalis Lipsky) in Hyrcanian forests (Iran). Annals of Forest Science, 73, 371-380. https://doi.org/10.1007/s13595-015-0525-2

Salve, P. R., Maurya, A., Wate, S. R., Devotta, S. (2008). Chemical Composition of Major Ions in Rainwater. Bulletin of Environmental Contamination and Toxicology, 80(3), 242-246. https://doi.org/10.1007/s00128007-9353-X

Schrumpf, M., Zech, W., Axmacher, J., \& Herbert V. M. Lyaruu. (2006). Biogeochemistry of an Afrotropical Montane Rain Forest on Mt. Kilimanjaro, Tanzania. Journal of Tropical Ecology, 22(1), 77-89. Retrieved from http://www.jstor.org/stable/4092145

Suertegaray, D. M. A., \& Silva, L. A. P. (2009). Tchê Pampa: Histórias da natureza gaúcha. In V. P. Pilar (Ed.), Campos sulinos: conservação e uso sustentável da biodiversidade (pp. 42-59). Brasília: MMA. 
Valente, M. L., Schumacher, M. V., Corrêa, R. S., Araújo, E. F., \& Trüby, P. (2016). Quantificação de nutrientes na precipitação em um plantio de Eucalyptus urophylla $\times$ Eucaluptus globulus subsp. Maidenii, Eldorado do Sul, RS. Scientia Forestalis, 44(109), 249-259. https://doi.org/10.18671/scifor.v44n109.24

Viera, M., \& Schumacher, M. V. (2010). Deposição de serapilheira e de macronutrientes em um povoamento de acácia negra (Acacia mearnsii De Wild.) no Rio Grande do Sul. Ciência Florestal, 20(2), 225-233. https://doi.org/10.5902/198050981848

Vujović, D., \& Milić-Petrović, B. (2016). Analysis of bulk precipitation chemistry in Serbia for the period from 1982 to 2010. Journal of Atmospheric Chemistry, 73, 101-116. https://doi.org/10.1007/s10874-015-9318-0

Wang, X. P., Wang, Z. N., Berndtsson, R., Zang, Y. F., \& Pan, Y. X. (2011). Desert shrub stemflow and its significance in soil moisture replenishment. Hydrology and Earth System Sciences, 15, 561-567. https://doi.org/10.5194/hess-15-561-2011

Wang, X., Zhang, Y., Wang, Z., Pan, Y., Hu, R., Li, X., \& Zhang, H. (2013). Influence of shrub canopy morphology and rainfall characteristics on stemflow within a revegetated sand dune in the Tengger Desert, NW China. Hydrological Processes, 27, 1501-1509. https://doi.org/10.1002/hyp.9767

Zhang, Y., Wang, X., Hu, R., Pan, Y., \& Zhang, H. (2013). Stemflow in two xerophytic shrubs and its significance to soil water and nutrient enrichment. Ecological Research, 28, 567-579. https://doi.org/ 10.1007/s11284-013-1046-9

\section{Copyrights}

Copyright for this article is retained by the author(s), with first publication rights granted to the journal.

This is an open-access article distributed under the terms and conditions of the Creative Commons Attribution license (http://creativecommons.org/licenses/by/4.0/). 